\title{
Di-transitive Constructions in Persian Based on the Minimalist Program
}

\author{
Azam Shahsavari ${ }^{1}$ \\ ${ }^{1}$ Department of Linguistics, Islamic Azad University, Science and Research Branch, Tehran, Iran \\ Correspondence: Azam Shahsavari, Department of Linguistics, Islamic Azad University, Science and Research \\ Branch, Tehran, Iran. Tel: 98-912-687-3925. E-mail: a.shahsavari60@yahoo.com
}

Received: June 13, 2016 Accepted: July 5, 2016 Online Published: December 1, 2016

doi:10.5539/ijel.v6n7p8 URL: http://dx.doi.org/10.5539/ijel.v6n7p8

\begin{abstract}
This article studies the structure of double-object constructions, a challenging structure in Persian, based on Bowers' $(1993,2001)$ minimalist approach. The major goal here is to evaluate the effectiveness of Bowers' approach in analyzing such constructions. First, we reviewed the Persian grammarians' analyses of transitivity and the continuity of the transitive system which claims that there are verbs with one object at one side of this continuum and verbs with two objects at the other side. Based on this analysis, transitivity differs from verb to verb. In other words, di-transitive verbs are more transitive than other verbs because they have to get two objects so that the omission of one of these objects makes the construction ungrammatical. In this study we used Bowers' approach $(1993,2001)$, i.e., double predication phrase design, to analyze the above mentioned structures in Persian. Later the sequence of the direct-indirect object was identified to be the unmarked grammatical sequence in Persian based on native speakers' language intuition.
\end{abstract}

Keywords: di-transitive constructions, double predication phrase, direct object, indirect object, unmarked sequence

\section{Introduction}

Linear and non-identical phrase structure, considered previously as applicable to all phrases, came under question in 1970, and $\overline{\mathrm{X}}$ - theory which believed in binary principal in phrases and projections was proposed. According to this theory, each maximal projection consists of three projections. The first projection contains the specifier; the second one, the head; and the third, the complement. This model was appealing for linguists interested in drawing phrase structures of other languages. Even though the transformational linguistics paid great attention to this model which had an effective role in its achievements, the model faced some problems in drawing the phrase structure of di-transitive verbs. The problem of drawing verb phrases containing double object in $\overline{\mathrm{X}}$ - theory was that the double objects appeared as several branch structures, two of which rooted in the $\overline{\mathrm{V}}$, which was contrary to the $\overline{\mathrm{X}}$ principle of the binary principal. So Larson (1988) tried to justify the structure of double object constructions in $\overline{\mathrm{X}}$ - theory. According to him, a verb phrase consists of two verb layers, one with a light verb head and the other with a lexical verb head. Based on Larson's (1998) analysis, the derivation of di-transitive constructions is similar to that of passive constructions. According to his ideas, the direct object which is the specifier of the verb phrase (Spec, VP) in D-structure, moves from its place to adjunct of $\overline{\mathrm{V}}$ as a result of an optional lexical process; and the indirect object which plays the role of head complement is a sister to the head $(\mathrm{V})$. But in S-structure, the indirect object moves from its original place to the null position of the spec-VP, and the lexical verb goes to the position of the light verb, so the structure permits the appearance of two objects. Jackendoff questioned Larson's pattern in 1990. He considered such a layer unnecessary and associated it with generative semantics. Larson insisted on his ideas by rejecting the criticism in the same year.

The idea of Larson (1990) about the structure of double objects in D-structure can be shown as:

1) John gave Mary a book. 


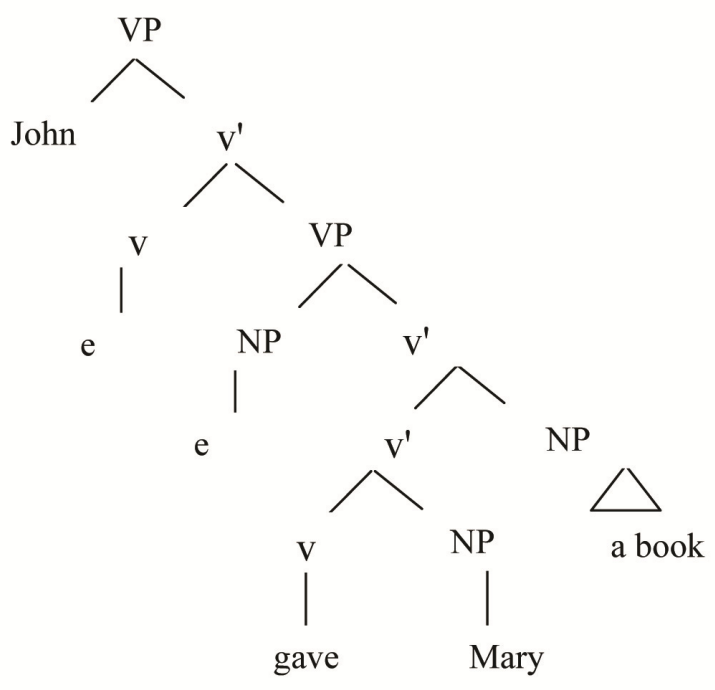

There are some problems with the analysis of Larson in the above diagram; some of which are:

a. If the direct object "a book" is $\overline{\mathrm{V}}$ 's sister, it must be an adjunct. Since adjuncts are optional, their omitting cannot make the sentence ungrammatical. But we see that this omission makes the sentence ungrammatical (Dabir-moqaddam, 1383/2004)

b. The model cannot support the constructions which have adjuncts, such as small clauses, other than double objects because in such constructions a direct object has to dominate the subject of these clauses. Yet according to this analysis, the direct object is an adjunct at the level of $\overline{\mathrm{V}}$, so it cannot c-command the subject of the nods under it and be co-indexed with it (Bowers, 1993).

2) *They fed the lions the meat [PRO e raw].

$$
\operatorname{PrP}
$$

Such shortcomings and deficiencies in Larson's approach made Bowers $(1993,2001)$ introduce a new paradigm to fix the flaws. This essay tries to describe and analyze Persian constructions based on Bower's theory (1993, 2001). The analysis of di-transitive constructions in Persian by this theory is a new step in applying one of the most modern syntactic approaches in linguistics for Persian language. In addition to domesticating this branch of knowledge, it can help the theory improve by evaluating and using it in Persian language. Since it is both descriptive and analytical, the research has used field study together with library research methods. It was also necessary to use the speakers' language intuition in addition to the author's to recognize the grammaticality and markedness of some structures.

The question here is whether this approach is sufficient to analyze di-transitive constructions and unmarked sequencing of direct and indirect objects in Persian. It is supposed that the theory is sufficient enough to analyze di-transitive constructions, and unmarked sequencing of direct and indirect objects in Persian.

\section{Literature of Di-transitive Constructions in Persian}

Alizade (1381/2002) discusses the structure of di-transitive constructions and their case assignment in his $\mathrm{PhD}$ thesis. He claims that adjacency is not necessary for the objects in Persian. Chomsky (1981) in a footnote mentions that adjacency is neither necessary nor applicable in the grammars with the sequence of subject-object-verb (SOV) because in such languages prepositional phrases stand generally between the verb and the direct object as indirect objects, and prepositional objects gain their case from their preposition, and the direct objects gain their case from their pre-verb positions. According to Alizade (1381/2002) there are two positions for direct objects:

a. at the specifier of VP [spec, VP] if the direct object is specific (moshakhas). As a result, the unmarked sequence of the verb phrase in S-structure will be subject-direct object-indirect object-verb.

b. subjacent to the main $\mathrm{V}$ (the sister of $\mathrm{V}$ ) if the direct object is unspecific (na-moshakhas). In this case the direct object will be at a lower level in the tree diagram and the sequence of the verb phrase in S-structure will be subject-indirect object-direct object-verb. 
Based on his analysis, the unspecific direct object comes adjacent to the main verb (sister to V) and gets its grammatical case and $\Theta$-role from the verb in this position, while the specific direct object, after getting its $\Theta$-role from the main verb, moves to the spec-VP which is an upper node in the tree diagram to check its accusative case by the Inflection head (I). The specific objects in this position can c-command the indirect object in the prepositional phrase to generate a grammatical structure.

Karimi (2005), in the third chapter of her book reviews "double object position hypothesis" and identifies Bowers' predication phrase which is between the tense and verb phrases as a verb phrase and the predication phrase as the complement of $\mathrm{V}$.

3)

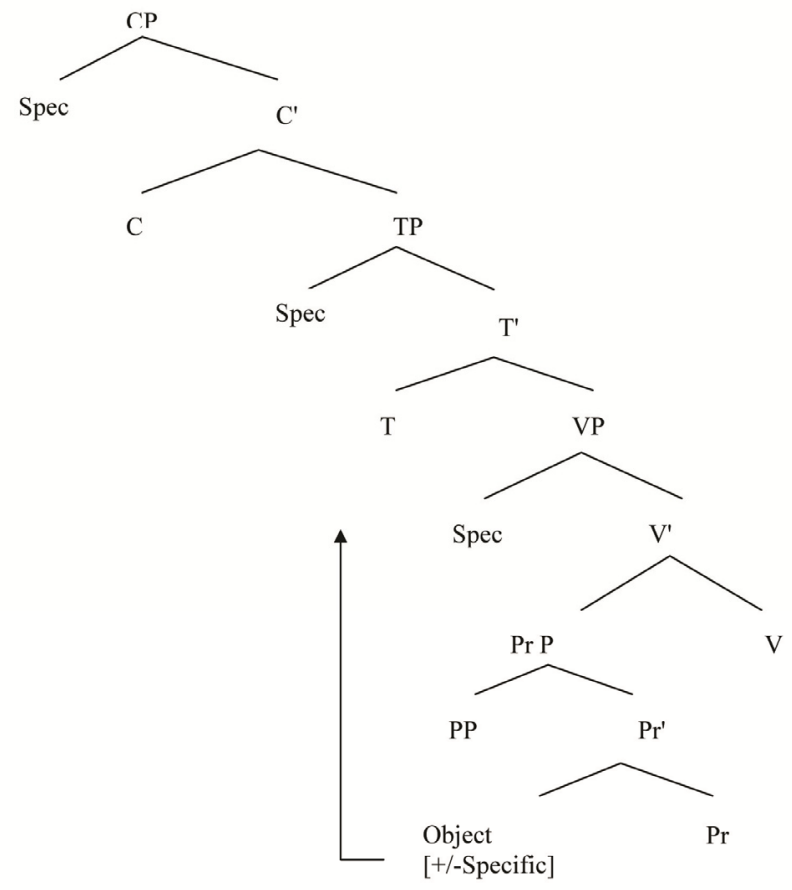

According to Karimi's (2005) analysis, the specific object moves to spec-VP for semantic interpretation. In her revised version, Karimi believes the generation of the two objects in the same place (complement of V) not in two different positions.

4)

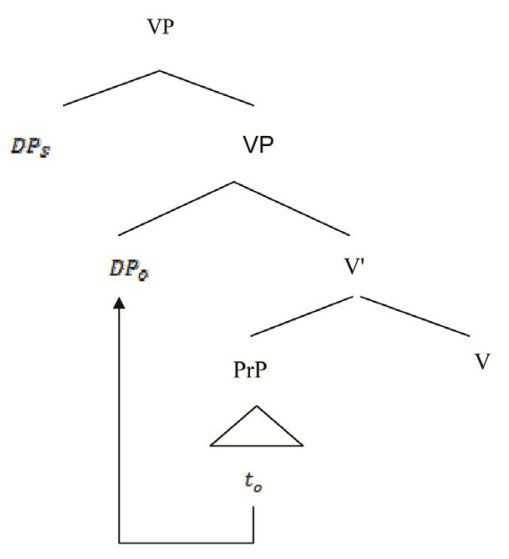

The interesting point is that the movement of the specific object to spec-VP is compatible with both Chomsky's ideas about arguments' interpretations in the area of VP and the lack of co-indexation of the direct object and the pronoun morpheme affixed to the indirect object when not being c-commanded by the direct object. 


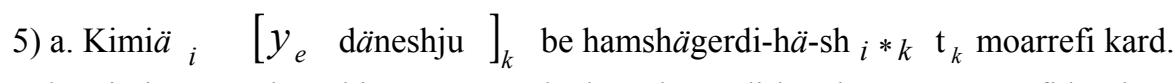

b. Kimiä $i$ ye däneshju-ro $k \quad$ be hamshägerdi-hä-sh ${ }_{i} / k$ moarrefi kard.

In (a), the object is unspecific; therefore, it should come after the indirect object, and even if it moves, it cannot c-command the pronoun affix and co-index with it; but in (b) the object is specific, and in an upper position to the morpheme, so it can be co-indexed with it because it c-commands that morpheme.

Mansouri (1384/2005), in his PhD dissertation, studies transitive constructions in Persian and after investigating the behavior of 530 verbs, considers transitivity in Persian as a continuum having at one end the verbs which are completely intransitive and at the other those completely transitive. As a result, dividing the verbs into two categories of transitive and intransitive is indefensible. Based on Mansouri's (1384/2005) analysis, we can divide verbs in Persian into six categories from completely intransitive to completely transitive (di-transitive) ones. He believes Larson's $(1988,1990)$ continuity model is the best way to analyze this structure.

Vaezi (2013) believes that "comprehensive and multi-dimensional interpretation" of di-transitive constructions can be attained by relying on syntactic-pragmatic explanations.

Haspelmath (2015) defines di-transitive constructions as "syntactic constructions with three arguments, an agent (A), a theme (T), and a recipient ${ }^{\circledR}$, which express an event of possessive transfer ("give," "lend," etc.) or an event of cognitive transfer ("tell," "show," etc.)".

\section{Theoretical Framework}

Some deficiencies in Larson's theory $(1988,1990)$ made Bowers publish essays in 1993, 2001, and 2002 to suggest some modifications in tree diagrams. The Predication Phrase is his first modification which was discussed in his first and second essays, and was considered sine qua non in the third one. Bowers (2001) believes that Predication is a traditional concept which implies the relationship between the subject and the predicate as two major elements of the sentence. According to him, predication is the most important relationship both in syntax and semantics (ibid.). The Predication Phrase can be said to be a substitute for Larson's VP shell nod. In Bowers' analysis, the main and small (verb-less, and tense-less) clauses hold the same structural relations, i.e. small clauses make predication phrases like main clauses (Bowers, 2001). According to Bowers, predication is a functional category; and the subject of the main clause occupies specifier position of the Predication Phrase (spec, PrP) and the object sits in the specifier position of the Verb Phrase (spec, VP); therefore, the verb has to move to the head of the PrP. Another modification in Bower's paradigm is the introduction of a functional category called the Transitive Phrase (TrP). He believes this $\operatorname{TrP}$ is between the PrP and VP, and NPs move to the [Spec, $\mathrm{TrP}]$ to check their accusitivity through $\operatorname{TrP}$ head. According to Bowers' analysis, the motivation for subject movement from the [spec, PrP] to the [spec, TP] is to check its nominative case with the TP head (Dabir-moqaddam, 1383/2004). Bowers $(1993,2001)$ claims that the only way to analyze di-transitive constructions is to acknowledge double-predication constructions, i.e. as we consider two PrPs for di-transitive constructions (one causative (e.g., make and have) and one non-causative), in English, we should consider two PrPs for double-object constructions. In other words, we must have two PrPs one of which is the complement of TP which is in turn the complement of VP with an abstract verb head, and the subject sits in its spec. position. This is called the Upper PrP; and the second PrP is called the Lower PrP and is the complement of the upper VP and the indirect object comes at its specifier, but to attain case, it moves to the upper [Spec, VP]. The complement of the indirect object is another VP which the direct object is in its Spec. Based on Bowers' analysis, the indirect object moves from its main position as the specifier of the lower PrP to the specifier of the upper VP, so it can have the condition to get floating quantifiers. The VP head moves from its original position in the lower VP to the lower PrP head and from there to the upper VP head to check the characteristic of [+Caus] and then to the upper PrP head for case marking to the subject of the lower PrP as below:

6)

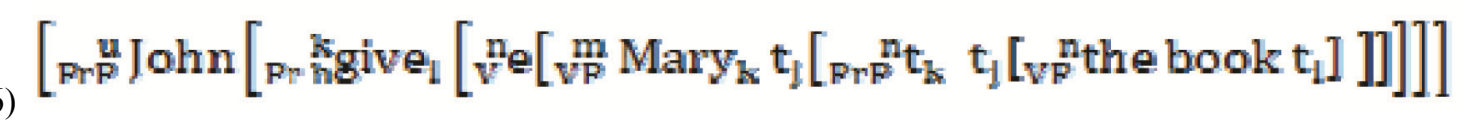

Based on this theory, the deep structure and the derivation processes of di-transitive constructions are similar to complex causative constructions. The only difference between causative and di-transitive constructions is that, in causative constructions, there is a lexical causative verb in the upper $\operatorname{PrP}$ and a non-causative lexical verb in the lower PrP, but in di-transitive constructions there only exists one apparent lexical verb in the lower PrP and in the upper PrP there is only an abstract [+Caus] to check the causativity of the lower verb (Bowers, 1993). 
7)

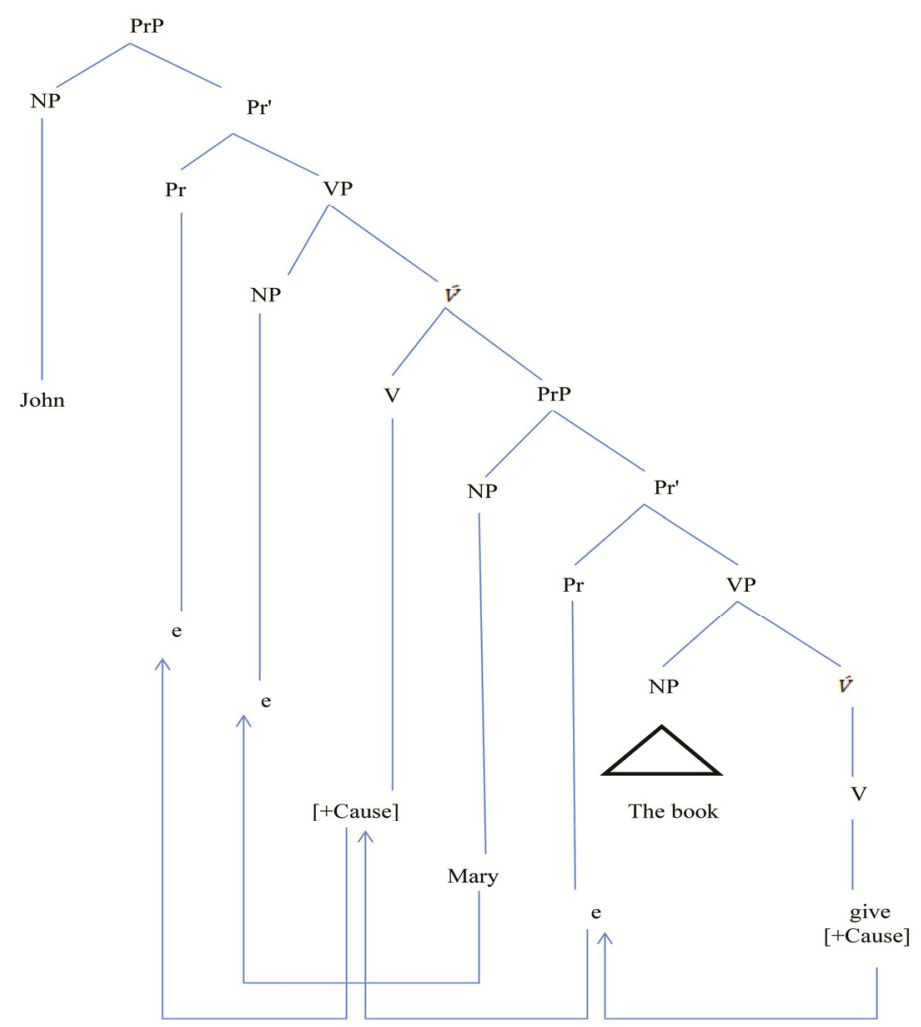

Accordingly, it can be said that di-transitive constructions are like causative constructions which hold predication concepts such as "John has a book", and dative constructions (baraaei) (having objects of prepositions) are the result of the embedding of concepts such as "the book belongs to Mary" under the causative verb.

8)

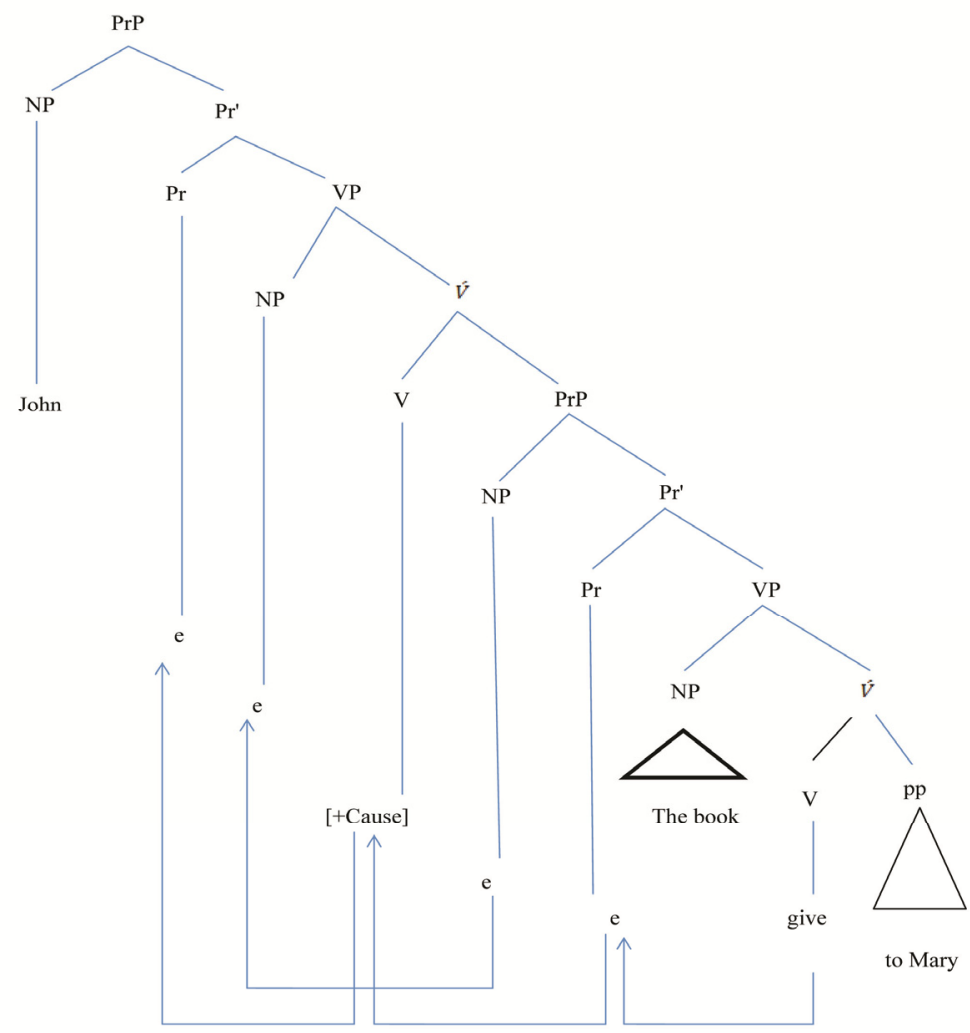


According to Bowers $(1993,2001)$, dative constructions are also causative forms of non-causative sentences, just like di-transitive constructions. On the basis of this approach, in the dative constructions indirect object is the complement of the upper VP head, and the direct object is at the lower [Spec, VP]; however, the direct object then moves to the Specifier of the upper VP to check its accusative case and the VP head first goes to the lower PrP head and then to the upper verb head, and finally to the upper PrP head to merge with [+Caus] characteristic.

Since Bowser's analysis of di-transitive constructions has all the following features, it can be claimed to be a proper and efficient framework for the analysis of such structures.

a. Based on this approach, the indirect object asymmetrically c-commands the direct object (which is compatible with Lesnik and Barss' approach, 1986)

b. The direct object c-commands the subject of complementary small clauses and is co-indexed with it.

c. Since in this analysis the indirect object appears to the left of the direct object, i.e., at the lower Spec. PrP and moves from there to the upper Spec, VP, it has the condition of having floating quantifiers.)

d. The sequence of elements (V-IO-Q-DO-Sc) has been observed in this approach.

e. Another advantage of this analysis is that it can properly case-mark both the direct and the indirect objects. The direct object which is in the lower Spec, VP receives its accusative case from the lower VP head, and the indirect object which is in the upper Spec, PrP moves to the upper Spec, VP to get its accusative case from the upper VP head; therefore, there is no need to distinguish structural case from inherent case as Chomsky did (Bowers, 2001).

f. By employing this analysis and the existence of PrPs, there is no need to accept the category of small clauses; because, according to this analysis, the $\operatorname{PrP}$ which has the functional predicate head with predicative meaning includes both main and small clauses. Another consequence of accepting this analysis is that the basic syntactic structure of language propositions, regardless of the word order (linear precedence), could be considered fixed and limited.

g. And as a final consequence, all lexical and functional categories with fixed and specific syntactic and semantic distribution in universal grammar could be integrally described according to a limited and modified version of the $\overline{\mathrm{X}}$ theory.

\section{Di-transitive Constructions Analysis in Persian}

The di-transitive construction has received little attention as an independent structure in Persian and it has only been mentioned in the discussions about complements and objects. So, here we will refer to those discussions that are related to the present study.

Di-transitive (three argument) constructions consist of an external argument (the subject), and two internal arguments (the direct and the indirect objects). Since in these structures the existence of the direct object is certain, there is no doubt in their transitivity, yet the necessity of the indirect object differs from one sentence to another.

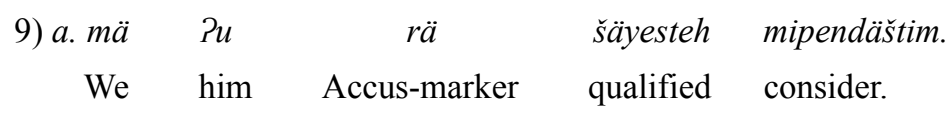

We consider him qualified.

$\begin{array}{clll}\text { b. mädar } & k u d a k & r a ̈ & \text { busid. } \\ \text { Mom } & \text { the kid } & \text { Accus-marker } & \text { kissed. }\end{array}$

Mom kissed the kid.

$\begin{array}{cccccccc}\text { c. koštigir-e } & \text { iräni } & \text { medäl-e } & \text { talä } & \text { rä } & \text { be gardan ävixt. } \\ \text { Wrestler } & \text { Iranian medal } & \text { gold } & \text { Accus-marker } & \text { to his neck hung. }\end{array}$

The Iranian wrestler hung the gold medal to his neck.

$\begin{array}{ccccl}\text { d. } ⿱ u & \text { ketäb-e } & \text { barädaram } & r a ̈ & \text { dozdid. } \\ \mathrm{He} & \text { book } & \text { my brother } & \text { Accus-marker } & \text { stole. }\end{array}$

He stole my brother's book.

$\begin{array}{rlllll}\text { e. Ali } & \text { ketäb } & r \ddot{a} & r u-y e & \text { miz } & \text { gozäšt. } \\ \text { Ali } & \text { the book } & \text { Accus-marker } & \text { on } & \text { the desk } & \text { put. }\end{array}$


Ali put the book on the desk.

$\begin{array}{rlll}f . \text { Ali } & \text { ketäb } & r a ̈ & \text { be Hassan däd. } \\ \text { Ali } & \text { the book } & \text { Accus-marker } & \text { to Hassan gave. }\end{array}$

Ali gave Hassan the book.

Ali gave the book to Hassan.

Traditional grammarians (Shari'at, 1379/2000; Qarib et al., 1370/1991; and Bateni, 1370/1991) have divided Persian verbs into three groups, intransitive, transitive, and dual- functioning on the basis of the existence of the direct object with phonetic representation. In modern minimalist analysis (Haqbin, 1379/2000, Mansouri, 1384/2005), transitive system is considered a continuum, at one end of which completely intransitive verbs, and at the other end, completely transitive ones. According to Mansouri's analysis (1384/2005) we can divide the transitive verbs into several subgroups. Some transitive verbs get only one NP as their complement and let no other NPs or Prepositional Phrases (PPs) participate in the completion of the verb meaning. Some of these verbs are: parastidan (to worship), busidan (to kiss), buyidan (to smell), and fahmidan (to understand). E.g.:

$\begin{array}{clll}\text { 10) } m a ̈ d a r & k u d a k & r a ̈ & \text { busid. } \\ \text { Mom } & \text { the kid } & \text { Accus-marker } & \text { kissed. }\end{array}$

Mom kissed the kid.

Another group of verbs get a PP added to the verb, in addition to an NP, as their object. These verbs are somehow closer than the previous ones to di-transitive verbs, so they appear as transitive verbs with a PP in the continuum after the first group. PP is an integral part of such verbs. E.g.:

$\begin{array}{clllll}\text { 11) koštigir-e } & \text { iräni } & \text { medäl-e } & \text { talä } \text { rä } & \text { be garden ävixt. } \\ \text { Wrestler } & \text { Iranian } & \text { the medal gold Accus-marker to his neck hung. }\end{array}$

The Iranian wrestler hung the gold medal to his neck.

Some of these kinds of verbs are: (be garden) ävixtan [hang (to neck)], (be chäh) andäxtan [throw (into well)], ... Since the PP and the verb are interdependent in this group of verbs, the sequence of the indirect object-the direct object in which the PP comes before the direct object is marked. E.g.:

$\begin{array}{ccclcll}\text { 12) ?? koštigir-e } & \text { iräni } & \text { be } \text { garden } & \text { medäl-e } & \text { talä } & \text { rä } & \text { ävixt. } \\ \text { Wrestler } & \text { Iranian } & \text { to his neck } & \text { the medal } & \text { gold } & \text { Accus-marker } & \text { hung. }\end{array}$

The Iranian wrestler hung to his neck the gold medal.

The third group consists of those verbs that, in addition to the subject NP and the direct object NP, get a third maximal projection which attributes the action to the direct object; these maximal projection are not considered indirect objects. In traditional grammar these maximal projections are called object complement (tamiz). Such verbs which need three NPs are called relative mono-transitive verbs which are closer to di-transitives in comparison to those in the previous groups. Some verbs in this group are: pendäštan (to suppose), nämidan (to name), hesäb kardan (to coount), be šomär ävardan (to include), and qalamdäd nemudan (to call).

The forth group are those verbs which can simultaneously appear as both mono-transitive and di-transitive (with optional PP and NPs). E.g.:

$\begin{array}{rlllll}\text { 13) } a . P u & k e & r a ̈ & a z & \text { barädaram } & \text { dozdid. } \\ \mathrm{He} & \text { a book } & \text { Accus-marker } & \text { from } & \text { my brother } & \text { stole. }\end{array}$

He stole a book from my brother.

$\begin{array}{ccccc}\text { b. } ⿱ u & \text { ketab-e } & \text { barädaram } & \text { rä } & \text { dozdid } . \\ \text { He } & \text { book } & \text { my brother } & \text { Accus-marker } & \text { stole. }\end{array}$

He stole my brother's book.

In this group, verbs need a PP in addition to the NP. Therefore, they are inclined to be di-transitives more than the verbs in the third group. They are called floating (shenaavar) di-transitive verbs. Some of these verbs are: gereftan (to get), dozdidan (to steal), robudan (to steal), ... .

The fifth group consists of those verbs which do not specifically come with two objects, but can be claimed to be di-transitives because they have to get two other NPs other than the subject NP. So, they are much closer to di-transitives than those verbs in other four groups. These verbs have two NPs one of which is the direct object 
and the other the adverb (adjunct). That is why they are not considered perfect di-transitives but mono-object di-transitives (Mansouri, 1384/2005). Some verbs of this group are: gozäštan (to put), qarär dadan (to place), käs̆tan (to plant), täbidan (to shine), gardändan (to turn). E.g.:

\begin{tabular}{|c|c|c|c|c|}
\hline 14) Ali & ketäb & $r \ddot{a}$ & ru-ye & $m i z$ \\
\hline Ali & the book & Accus-marker & on & the desk \\
\hline
\end{tabular}

Ali put the book on the desk.

And finally the last group which consists of those verbs called perfect di-transitives which come with two clear obligatory objects; the omission of either object makes the structure ungrammatical. Since these verbs get two objects, they appear at the other end of the continuum as perfect di-transitives. Some of these verbs are: dädan (to give), ferestädan (to send), resändan (to deliver), sepordan (to hand), gereftan (to get), šenäsändan (to introduce), šurändan (to uprise), ...

In this group, if the verb comes before the PP, the preposition will be omitted while there was not such a case in the previous group in which the PP played the role of the adverb. E.g.:
15) a. Ali
ketäb $r \ddot{a}$ däd
Hassan. (Perfect di-transitive)
Ali the book
Accus-marker
gave Hassan.

Ali gave Hassan the book.
b. Ali ketäb rä
Ali the book Accus-marker
gozäšt
put
ru-ye
on
miz. (Mono-object di-transitive)

Ali put the book on the desk.
c. ${ }^{*}$ Ali ketäb rä gozäšt miz. (Ungrammatical)
Ali the book Accus-marker put the desk.

Ali put the book the desk.

As mentioned above, only those verbs with two obligatory direct and indirect objects can be called perfect di-transitives. It must be noted that not accepting the existence of the functional double-predication node and following Larson's $(1988,1990)$ analysis causes some problems in analyzing such structures. Some of these problems are:

a. According to Larson, the direct object is v' node sister, so it must be considered an adjunct and since adjuncts are optional, their omission should not make the sentence ungrammatical, but this omission makes the sentence ungrammatical. (Dabir-moqaddam, 1383/2004)

b. The direct object does not c-command the subject of complementary small clauses (PRO), and is not co-indexed with it.

c. Since the indirect object appears to the right of the direct object in the position of [compl, V] in derivational processes, and then moves to the [Spec, VP], it does not have the properties of the floating quantifier.

d. The sequence of elements in this approach is: verb-indirect object-direct object-quantifier-complementary small clauses (V-IO-DO-Q-Sc), i.e., the floating quantifier cannot come neighboring to the indirect object; therefore the resulting construction is ungrammatical.

The following structures are analyzed according to Bowers' approach $(1993,2001)$.
16) Ali
ketäb
$r \ddot{a}$
be Ahmad
däd.
Ali the book
Accus-marker
to Ahmad
gave.

Ali gave the book to Ahmad. 


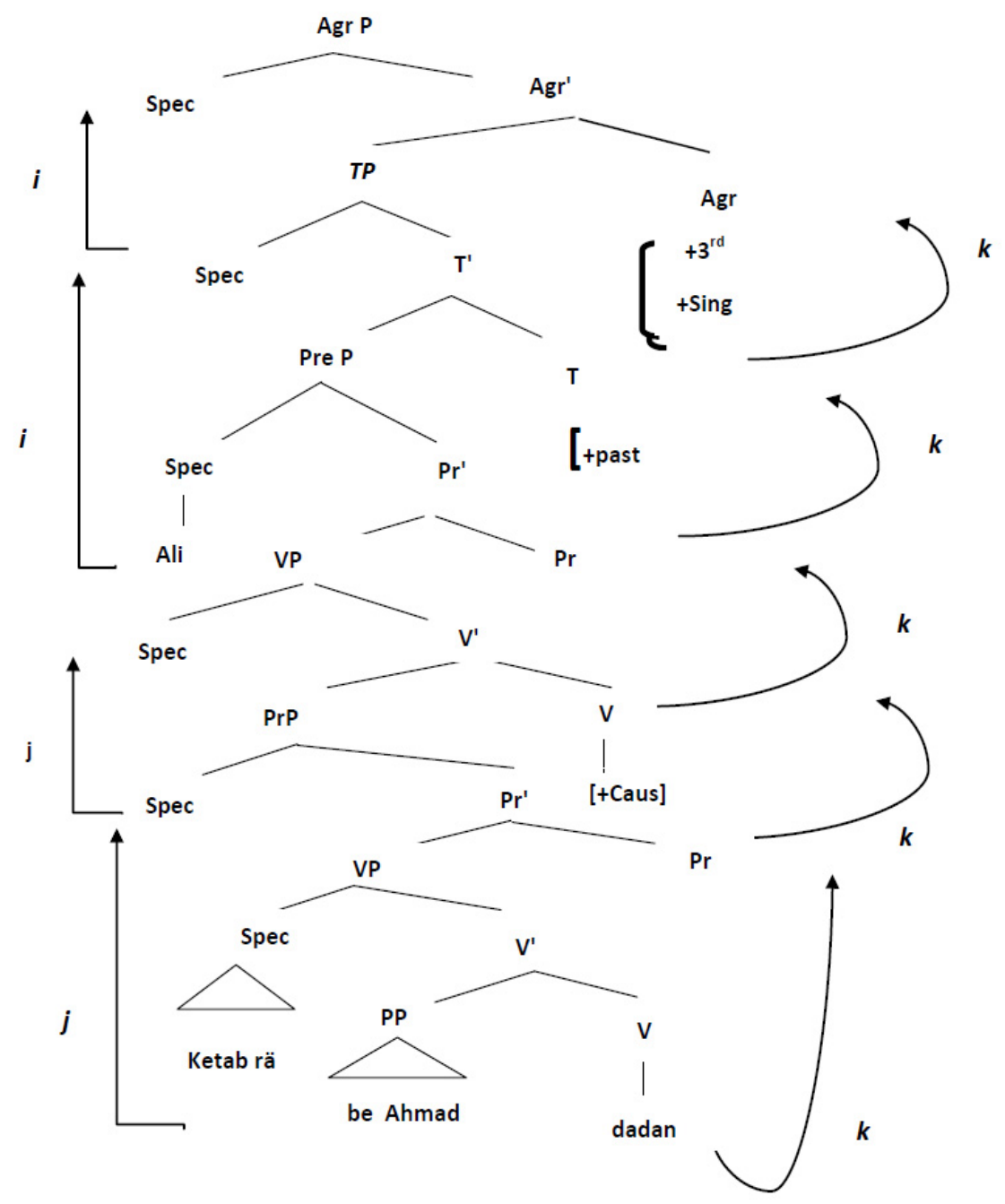

\section{The Sequence of the Direct and the Indirect Objects}

The sequence of the direct and indirect objects is one of the most attractive and controversial issues about the internal construction of verb phrases. According to Bowers (2001), arguments such as the direct objects come in the uppermost position, i.e., in the [spec, VP], complement clauses, if any, in the second position, i.e., between the direct and the indirect objects, and the indirect object, which is the verb complement, in the lowest or the third position. Bowers (2001) believes that the indirect object and adverbs under the governed by the verb appear to the right of (after) the direct object. Accordingly the sequence of elements in English is:

\section{Verb-direct object - (adverb) -indirect object}

From Bowers' viewpoint, it can be concluded that the basic sequence is the direct object-the indirect object. However, whether this sequence is basic in Persian, and the sequence of objects in Persian will be discussed in the following parts to see if Bowers' ideas can be applied for Persian constructions or not.

If the basic sequence of Persian objects is considered to be the direct-indirect object, their displacement in the following sentences should be justified:

17) a. Ali ketäb rä
Ali
the book
Accus-marker
to

be Ahmad däd.

Ali gave the book to Ahmad.

$\begin{array}{rrrrll}\text { b. Ali } & \text { be } & \text { Ahmad } & \text { ketäb } & \text { rä } & d \ddot{d} . \\ \text { Ali } & \text { to } & \text { Ahmad } & \text { the book } & \text { Accus-marker } & \text { gave. }\end{array}$

Ali gave Ahmad the book. 
Larson (1988) attributes the displacement of objects in English, and lack of it in some languages such as French, Italian, and Spanish, to this fact that the preposition in English is not case marking, so the indirect objects moves and the preposition will be omitted; but in French, Italian, and Spanish, the preposition is case marking (oblique case), so neither the object can move nor the prepositions be omitted. Data gathered from Persian do not justify this because if the indirect object moves and the preposition is omitted, the structure becomes ungrammatical as:

18) a. Ali ketäb rä be Ahmad däd.

Ali the book Accus-marker to Ahmad gave.

Ali gave the book to Ahmad.

$\begin{array}{rllll}\text { b. }{ }^{*} \text { Ali } & \text { ketä } & \text { rä } & \text { Ahmad } & \text { däd. } \\ \text { Ali } & \text { the book } & \text { Accus-marker } & \text { Ahmad } & \text { gave. }\end{array}$

Ali gave Ahmad the book.

$\begin{array}{rrrrrr}\text { c. Ali } & \text { be Ahmad ketäb } & \text { rä } & \text { däd. } \\ \text { Ali to Ahmad } & \text { the book Accus-marker } & \text { gave. }\end{array}$

Ali gave Ahmad the book.

$\begin{array}{rrcrl}\text { d. }{ }^{*} \text { Ali } & \text { Ahmad } & \text { ketäb } & \text { rä } & \text { däd. } \\ \text { Ali } & \text { Ahmad } & \text { the book } & \text { Accus-marker } & \text { gave. }\end{array}$

Ali gave Ahmad the book.

The author believes that the only reason for this movement may be because of stylistic conventions, but the quality of this movement is something which must be thoroughly investigated in future studies.

Now we should find a position for the moved indirect object in the Persian structure. One way is to suppose the indirect object is adjoined to Pr' node as an adjunct. However, the problem here is that the indirect object in this position must behave as an adverb and its presence or absence does not affect the grammaticality of the sentence. The indirect object, though not similar to the direct object, has such a critical role that is easily distinguished from an adverb. Therefore, considering the indirect object as an adjunct is not justifiable.

Another suggestion is to consider another maximal projection between PrP and VP. This is not of course the first time that such a projection is suggested. Collins (2003) suggested such a maximal projection in "Khoazian" language and called it "Ko Phrase". He gave this name to this maximal projection to avoid adding a new term to syntax.

Mansouri (1384/2005) did the same to the Persian language. He called this maximal projection "Intermediate Phrase" because it comes between the light VP and the lexical VP. Accordingly, the internal structure of the above examples can be shown as:

$\begin{array}{rllll}\text { 19) a. Ali } & \text { ketäb } & \text { rä } & \text { be Ahmad } & \text { däd. } \\ \text { Ali } & \text { the book } & \text { Accus-marker } & \text { to Ahmad } & \text { gave. }\end{array}$

Ali gave the book to Ahmad. 


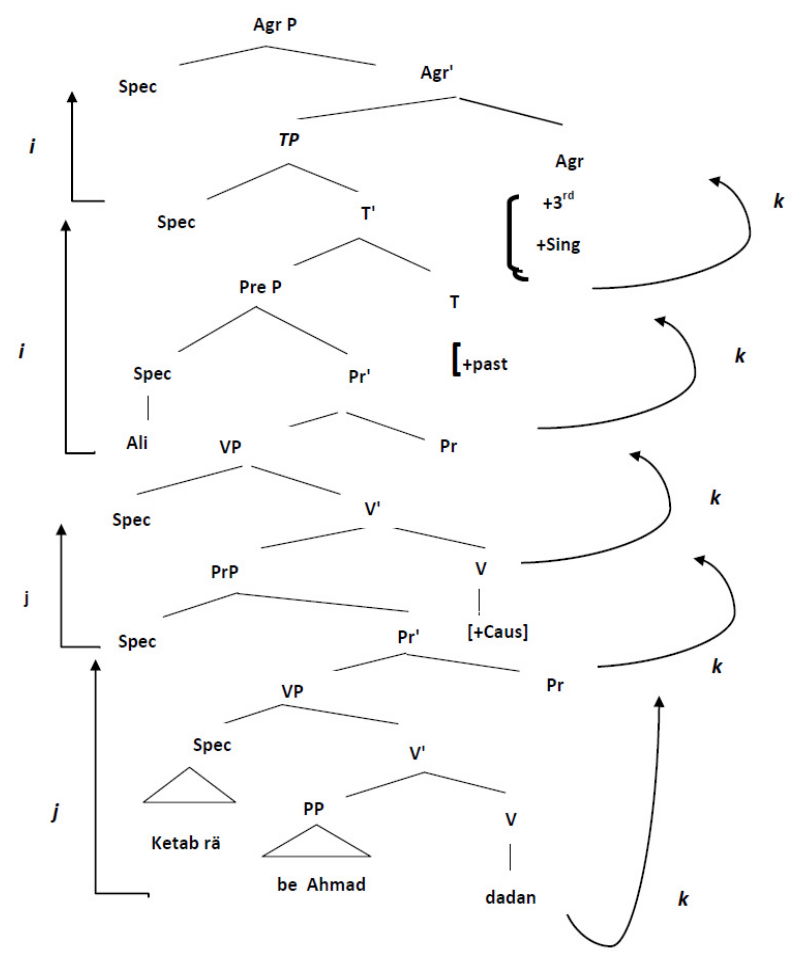

b. Ali be Ahmad ketäb

$r \ddot{a}$

däd.

Ali to Ahmad the book Accus-marker gave.

Ali gave Ahmad the book.

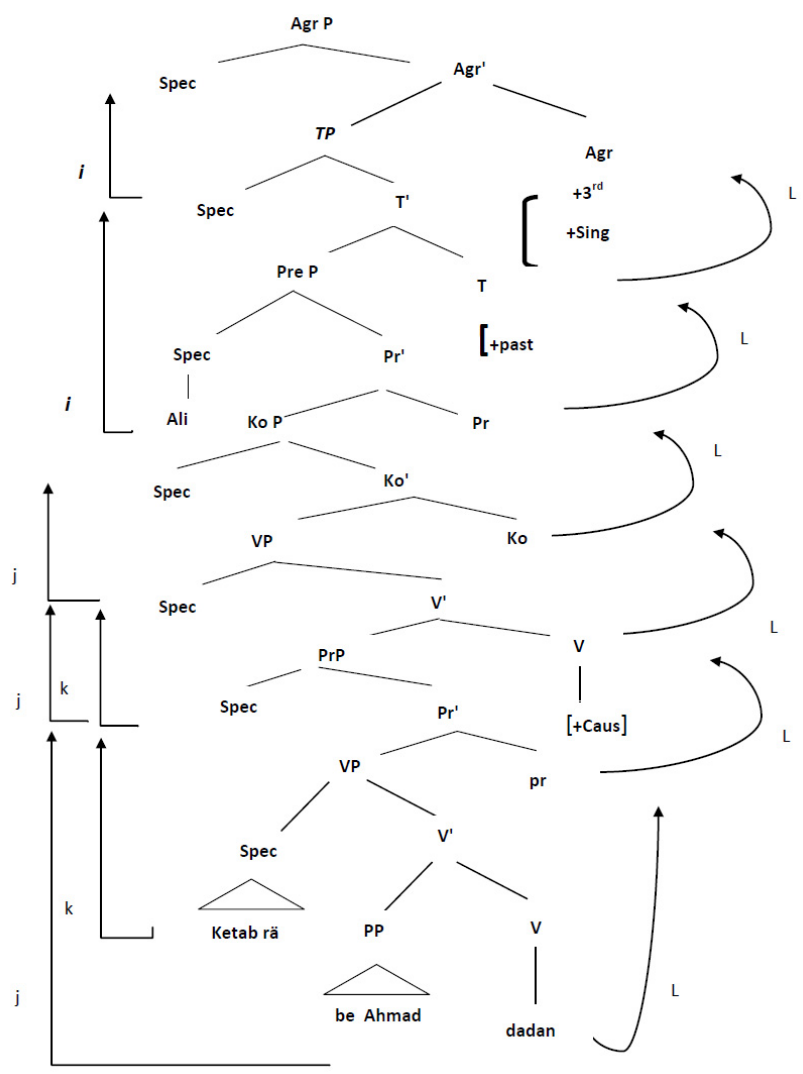


Another reason that clearly shows the necessity of such a projection (between PrP and VP) and accepting the sequence of the direct object-the indirect object as an unmarked sequence is that with the movement of the indirect object and the omission of its preposition, the structure becomes ungrammatical. Therefore, it is justified to have another projection between the $\operatorname{PrP}$ and VP if accepting the sequence of the direct object-the indirect object as unmarked.

\section{Discussion and Conclusion}

This article discussed the analysis of di-transitive constructions based on Bowers' $(1993,2001)$ paradigm of double predication phrase. According to this analysis, the direct object (NP) which basically sits in the lower [Spec, VP] and asymmetrically c-commands other arguments such as the indirect object and complement clauses, first moves to the lower [Spec, PrP] and then to the upper [Spec, VP] to check its case; and the indirect object (PP) remains in-situ in its basic position, i.e. as the verb complement. The subject which is the external argument is at the upper [Spec, PrP]. The V head goes to the lower Pr and then to upper V and after merging with the "transitivity" feature, and passing through the upper Pr and T, finally sits in Agreement Phrase (AgrP) head. It can be, therefore, said that the present approach can properly analyze the di-transitive constructions which are very challenging in the Persian syntax.

After that, the sequence of the direct and the indirect objects was also discussed and after some syntactic argumentations and checking against Persian speakers' intuition it was found that the unmarked sequence of objects in Persian is the direct - indirect object.

\section{Acknowledgments}

I would like to express my greatest acknowledgement to Dr. Mohammad Dabir-moghaddam who assisted tremendously in conducting the study and critiquing the manuscript. This paper would not have been written at all without his help and assistance. I would also like to thank all my family members who patiently tolerated my engagement with the study.

\section{References}

Alizade, A. (2002). An Investigation on Verb Phrase Construction, Focusing on the Hypothesis of the Subject inside the Verb Phrase. PhD thesis in Linguistics, Faculty of Foreign Language and Literature, Tarbiat Moddares University, Tehran.

Barss, A., \& Lasnik, H. (1986). A Note on Anaphora and Double object. Linguistic Inquiry, 20, 141-172.

Bateni, M. R. (1991). The Description of the Persian Grammar. Tehran: Amirkabir publisher.

Bowers, J. (1993). The Syntax of Predication. Linguistic Inquiry, 24, 591-652.

Bowers, J. (2001). Predication. In M. Baltin \& C. Collins (Eds.), The Handbook of Contemporary Syntactic Theory (pp. 299-333). Malden, MA: Blackwell Publishers Inc. http://dx.doi.org/10.1002/9780470756416.ch10

Bowers, J. (2002). Transitivity. Linguistic Inquiry, 33, 183-224. http://dx.doi.org/10.1162/002438902317406696

Chomsky, N. (1981). Lectures on government and binding. Dordrecht: Foris.

Collins, C. (2003). The Internal Structure of VP in Jul'hoansi and =hoan. Studia Linguistica, 57(1), 1-25. http://dx.doi.org/10.1111/1467-9582.00095

Dabir-moqaddam, M. (1997). Complex verbs in Persian. Studies in the Linguistic Sciences, 27(2), 25-59.

Dabir-moqaddam, M. (2004). Theoretical Linguistics: Appearance and Development of Generative Grammar (2nd ed.). Tehran, I.R. Iran: Samt Publiishers.

Haqbin, F. (2003). The Transitive System. PhD Thesis in Linguistics, Faculty of Foreign Language and Literature, Allameh Tabatabaii University, Tehran, I.R. Iran.

Haspelmath, M, (2015). Ditransitive Constructions. Annual Review of Linguistics, 1, 19-41. http://dx.doi.org/10.1146/annurev-linguist-030514-125204

Karimi, S. (2005). A Minimalist Approach to Scrambling Evidence from Persian. Berlin, Germany: Walter de Gruyter GmbH \& Co. KG, D-10785. http://dx.doi.org/10.1515/9783110199796

Larson, R. (1988). On the Double Object Construction. Linguistic Inquiry, 19, 335-391.

Larson, R. (1990). Double Object Revisited: Reply to Jackendoff. Linguistic Inquiry, 21, 589-632.

Mansouri, M. (2005). Shell phrases in Persian. PhD thesis in Linguistics, Faculty of Foreign Language and 
Literature, Allame Tabatabaii University, Tehran, I.R. Iran.

Qarib, A. et al. (1991). The Persian Grammar (Five Masters) (9th ed.). Tehran, I.R. Iran: Ashrafi Publications.

Radford, A. (1997). Syntactic Approach and the Structure of English. Cambridge: Cambridge University Press. http://dx.doi.org/10.1017/CBO9781139166706

Radford, A. (2004). Minimalist Syntax: Exploring the Structure of English. Cambridge: Cambridge University Press. http://dx.doi.org/10.1017/CBO9780511811319

Shari'at, M. J. (2000). Simple Persian Grammar. Tehran, I.R. Iran: Asatir publications.

Vaezi, H. (2013). Ditransitive Verbs in Persian: Interaction between Syntax and Discourse. Language Related Research, 5(5).

\section{Copyrights}

Copyright for this article is retained by the author, with first publication rights granted to the journal.

This is an open-access article distributed under the terms and conditions of the Creative Commons Attribution license (http://creativecommons.org/licenses/by/4.0/). 